\title{
Energy consumption pattern and renewable energy alternatives in Madi Kalyanpur, Chitwan, Nepal
}

\author{
Sumitra Poudel ${ }^{1 *}$, Narayan Prassad Chaulagain ${ }^{2}$ and Manoj Aryal ${ }^{3}$ \\ ${ }^{1}$ Central Department of Enviroonmental Science, Tribhuvan University, Kathmandu \\ ${ }^{2}$ GIZ-Nepal, Kathmandu \\ ${ }^{3}$ Department of Environment, Government of Nepal, Kathmandu
}

\begin{abstract}
Energy consumption pattern and greenhouse gases emission are interrelated. The unsustainable use of biomass and widespread use of commercial energy are of the major sources of greenhouse gas emission. The alternative to kerosene for lighting is solar home system (SHS), which is one of the potential renewable technologies for rural electrification. The present study has analyzed household energy consumption pattern and greenhouse gases emission from energy consumption practices as well as environmental and economic benefits of SHS in Madi Kalyanpur Village Development Committee of Chitwan district. For the purpose, the primary data were collected through household questionnaire survey, key informant interview (KII) and focus group discussion (FGD). The analysis has shown that $22 \%$ of household use all types of energy, i.e. fuel-wood, LPG (liquefied petroleum gas), biogas and SHS as the sources of energy. Thirty-five percent households use fuel-wood, LPG and SHS, $24 \%$ use fuel-wood, biogas and SHS, 1\% used LPG and SHS, 5\% use biogas and SHS, 4\% use LPG, biogas and SHS and $9 \%$ use fuel-wood and SHS as a source of energy. Almost all people have been using SHS for the lighting purpose. The average annual greenhouse gases emission per household from fuel-wood and liquefied petroleum gas consumption was 7.89 ton and 0.17 ton of $\mathrm{CO}_{2}$ equivalent respectively. Typically, a $40 \mathrm{Wp}$ SHS reduced the consumption of kerosene by 42 liter annually for lighting that displaced 0.11 ton of $\mathrm{CO}_{2}$ equivalent per household per year. The simple payback period for typically $40 \mathrm{Wp}$ SHS was found to be nine years with no subsidy, seven years with subsidy from Alternative Energy Promotion Centre and two years with Indian Government Grant. Similarly, the benefit-cost ratios were found to be 3.1, 3.5 and 4.6 for the systems with no subsidy, with AEPC subsidy and with Indian Grant, respectively.
\end{abstract}

Key words: Cost-benefit Ratio, Cost Payback Period, Greenhouse Gases Emission, Solar Home System

\section{Introduction}

Biomass is an indigenous energy source in Nepal. Three broad types of energy sources exist in Nepal: commercial, traditional and alternative energy (WECS, 2010). Energy that is environmentally friendly and can be used repeatedly without depletion is regarded as a renewable energy. This includes energy like wind, solar and geothermal energy. Speaking strictly, the for ms of renewable energy are environmentally favorable, with no significant negative impacts and are economically viable (Upadhaya, 2008).

In Nepal, the solar energy has been used traditionally for drying the crops, clothes, fuel-wood and crop residues. The solar energy potential in Nepal is estimated to be about 26 million MW (CRT/N, 2005). The first recorded use of Solar PV in Nepal can be traced back to 1963, when Civil Aviation Authority of Nepal installed a Solar PV system in Bhadrapur, Jhapa airport to $r$ un navigation equipment. Its use for domestic electrification started in July 1993

${ }^{*}$ Corresponding author, email address: sumitra.poudel08@gmail.com when Pulimarang Solar Village Electrification Project (PSEP) was initiated and implemented by Centre for Renewable Energy (CRE) with the financial support from Solar Electric Light Fund (SELF), a USA based non-profit or ganization. The use of Solar PV for domestic electrification gained momentum from 1996, since when Alternative Energy Promotion Centre (AEPC) was established with the objective of developing and promoting renewable energy in Nepal. It for mulated the policy to provide subsidies to the household in rural areas willing to install SHS (AEPC/ESAP, 2010).

An immediate impact of solar home system (SHS) in the environment comes from its replacement of traditional sources of power for lighting like kerosene, candle. The SHS provides light even at night through battery storage, providing additional time to children for their study. The solar PV technology in Nepal has shown a tremendous growth. This unprecedented growth of solar 
PV in Nepal is mainly due to three reasons- good solar radiation potential, poor access to the national grid electricity throughout the country, and increasing power cuts in urban area (Malla \& Niraula, 2012). The number of SHS installation in the rural areas of Nepal by AEPC and other programs had already been more 3,30,000 as of July 2013 (AEPC, 2013).

The use of $\mathrm{k}$ erosene has negative impact on health and environment. Most of the household income was used to spend for kerosene and income-generating activities were limited. It was difficult for children to read in light of $\mathrm{k}$ erosene. To avoid these drawbacks of kerosene lighting, renewable energy technology has been emerged; among which SHS is best suited for the country like Nepal. The general perception of the people is that SHS is more costly than kerosene due to its high installation cost. Thus, this study has analyzed, whether SHS is really a viable option or not from the environmental and economic perspective. Madi Kalyanpur Village Development Committee (VDC) of Chitwan district (Buffer Zone of Chitwan National Park), still far from access to the grid electricity and almost all houses have installed SHS, was selected the sample VDC for the present study. Besides, only limited studies have been done regarding the potential of SHS to reduce greenhouse gases in consideration with economic prospects. Thus, the present research was car ried out to fulfill such research gap focusing on current energy consumption pattern along with the analysis of economic and environmental benefits of SHS.

\section{Materials and Methods}

The present study was of descriptive type and based on primary as well as secondary data. The area was selected purposively for the study, as there was already 698 SHS installed till $2010 \mathrm{AD}$ under subsidy scheme of AEPC (AEPC, 2010) and the area was deprived of grid electricity. By the year 2014, the installation of SHS has increased to 1339 (AEPC/NRREP, 2014). The number of sample households was calculated using the empirical formula (Arkin \& Colton, 1963; Paudyal, 2007). About 98\% of household has SHS, so all the households were assumed to be SHS users (according to KII and FGD).

$$
\text { Sample size, } n=\frac{N Z^{2} P(1-P)}{N d^{2}+Z^{2} P(1-P)}
$$

Where,

$\mathrm{n}=$ Sample size $(70)$

$\mathrm{N}=$ Total number of households (1705) (CBS, 2012)

$\mathrm{Z}=$ Abscission of normal curve, i.e. Confidence level (at 95\%, $\mathrm{Z}=1.96$ )

$\mathrm{P}=$ Estimated population proportion $(0.05$ this maximizes the sample size)

$\mathrm{d}=$ Margin of error limit $(+/-5 \%)$

The sample size was calculated as 70, but 86 samples (households) were taken which is also $5 \%$ of 1705 (total household). The total samples were first stratified among nine wards of the VDC along with its household proportion. Af ter that, samples were tak en with SHS user through household questionnaire sur vey. Ms-Excel was used for calculation and interpretation of the data. Using emission factor (EP A, 2014) in the data obtained from questionnaire survey, the GHGs emission from the current energy consumption practices and its reduction by introducing solar energy technology was obtained.

\section{Calculations}

\section{Estimation of green house gases (GHGs) emission and reduction potential}

The emission factors for various types of fuel combustion given by EPA (2014) were used for GHGs emission and reduction from respective fuels (Table 1). The global warming potential of GHGs is given in Table 2 .

Table 1 Emission Factors of Combustion of Various Fuels

\begin{tabular}{lll}
\hline S.N. & Fuel source & Emission factor $\left(\mathrm{CO}_{2} \mathrm{e}\right)$ \\
\hline 1. & Fuel wood & $1.830 \mathrm{~kg} / \mathrm{kg}$ \\
2. & Kerosene & $2.689 \mathrm{~kg} / \mathrm{lit}$ \\
3. & LPG & $2.953 \mathrm{~kg} / \mathrm{kg}$ \\
\hline EPA $(2014)$ &
\end{tabular}

Table 2 Global Warming Potential (GWP) Factors

\begin{tabular}{lll}
\hline S.N & GHG & 100 year GWP factor \\
\hline 1. & $\mathrm{CH}_{4}$ & 25 \\
2. & $\mathrm{N}_{2} \mathrm{O}$ & 298 \\
\hline (IPCC, 2007 cited in EPA, 2014)
\end{tabular}

\section{Simple cost payback period}

Payback period is defined as, in what year the total percentage of the purchase price is get back as a function of ener gy saving. It was simply calculated as;

$$
\text { Simple cost payback period }(\mathrm{CCP})=\frac{\mathrm{Cin}}{\mathrm{Cs}-\mathrm{Com}}
$$

Dhoubhadel (2010)

Where,

$\mathrm{C}_{\text {in }}=$ Installations cost of PV System, i.e. initial investment cost taken as average for $40 \mathrm{Wp}$, NRs 23,000, NRs. 17,000 and NRs 6,000 for no subsidy, with subsidy from AEPC and with Indian Gover nment Grant, respectively .

$\mathrm{C}_{S}=$ Annual cost saved by utilizing the PV system was taken as saving in ter ms of cost of k erosene consumed per year. Average value of fuel consumption per month (3.5 liter/month and operating and maintenance cost taken as constant, i.e. NRs. 300/year) prior to using SHS was calculated based on survey.

$\mathrm{C}_{\mathrm{om}}=$ Annual operation and maintenance cost of SHS was taken in terms of cost of distilled water consumed per year, cost of charge controller, bulb, wire, switch per year (NRs. 800 constant throughout lifetime of SHS) and assuming battery life of 5 years (batter y cost of NRs. 10,000).

\section{缕TU-CDES}




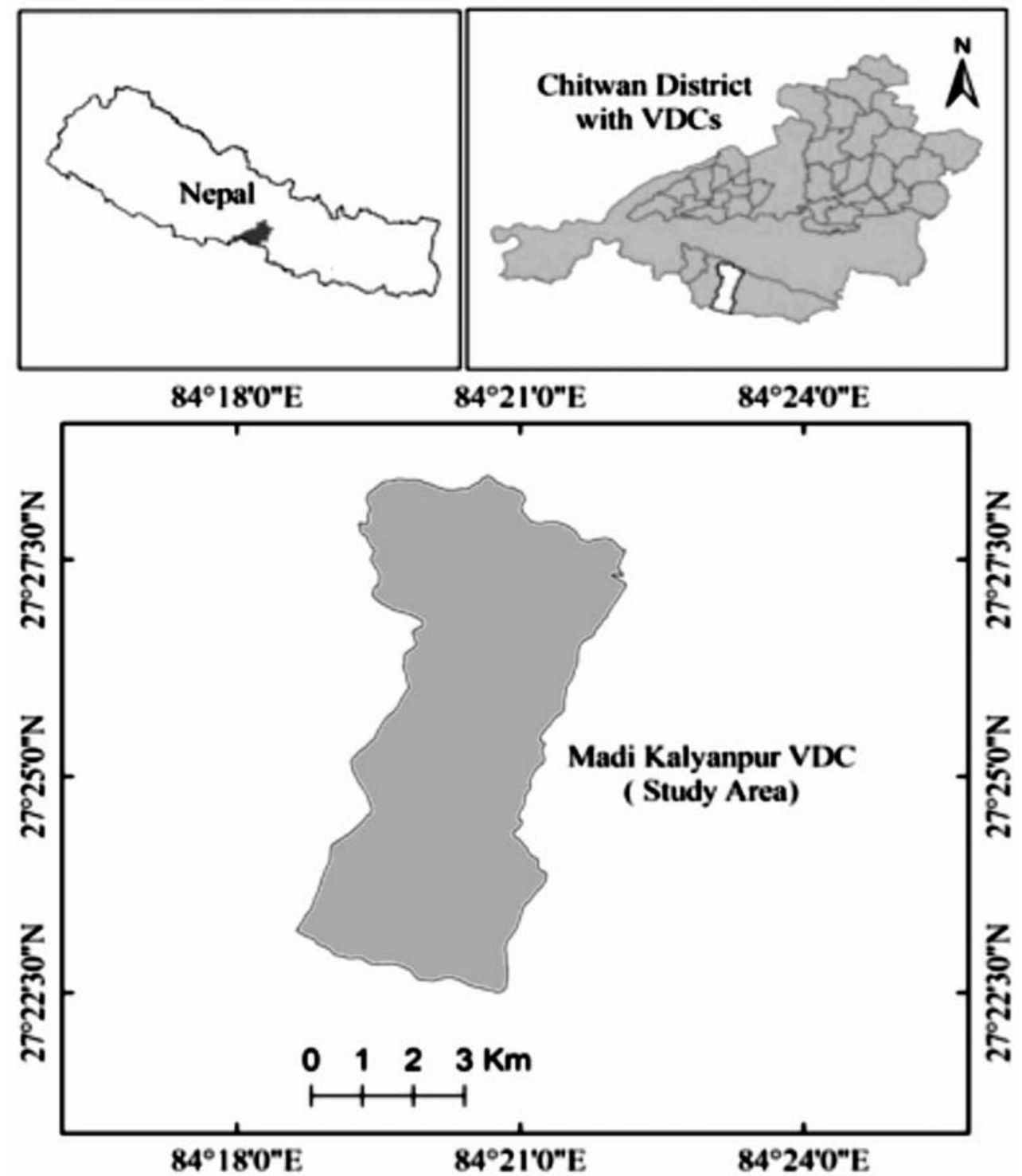

Figure 1 Location of the study area

\section{Financial benefit}

The amount of money saved from the kerosene consumption for lighting, due to installation of SHS for lifetime of 25 years (NRLE, 2014) was taken as financial benefit. The price of kerosene in 25 years lifetime was calculated with the inflation rate of $9.47 \%$ (NRB, 2014). The price of kerosene in the study area was NRs. 110 during survey.

\section{Cost-benefit analysis}

Cost-benefit analysis evaluates alternative risk levels by comparing the value of the expected gains with the associated costs. For costbenefit analysis, the cost of SHS installation and its operating and maintenance cost required for smooth $r$ unning of SHS was calculated, and benefit was calculated in ter ms of cost saved due to reduction in use of kerosene with inflation rate of $9.47 \%$ (NRB, 2014). Benefit-cost ratio (BCR) was estimated for the analysis of cost-benefit, where net present value (NPV) was calculated with $7 \%$ interest rate (NRB, 2014).

Mathematically, $\quad \mathrm{NPV}=\sum \frac{\mathrm{n}_{\text {Value } \mathrm{T}}}{\mathrm{T}=0{ }^{(1+\text { rate })^{\mathrm{T}}}}$

$$
\mathrm{BCR}=\frac{\mathrm{PV}_{\text {benefits }}}{\mathrm{PV}_{\text {costs }}} \quad \text { Shively \& Galopin (2014) }
$$

Where,

PV benefits $=$ Present value benefit

$\mathrm{PV}_{\text {costs }}=$ Present value cost

If $\mathrm{PV}$ benefits $/ \mathrm{PV}_{\text {costs }}>1$, option is considered feasible 


\section{Results and Discussion} Energy consumption scenario

Different household used different types of energy for fulfillment of their need. The result showed 22\% of household use all types of energy, i.e. fuel-wood, LPG, biogas and SHS as the source of energy, 35\% use fuel-wood, LPG and SHS, 24\% use fuel-wood, biogas and SHS, 1\% use LPG and SHS, 5\% use biogas and SHS, 4\% use LPG, biogas and SHS, and 9\% use fuel-wood and SHS as the source of energy (Fig. 2).

\section{GHG emission from energy consumption practices}

Fuel-wood was the main source of energy that contributed to the most in the emission of greenhouse gases. F uel-wood and LPG used per household per year was $4311 \mathrm{~kg}$ and $57 \mathrm{~kg}$ respectively that contributed about $7889.13 \mathrm{~kg}$ (7.89 ton) and $168.32 \mathrm{~kg}(0.17$ ton) of $\mathrm{CO}_{2}$-equivalent respectively. The high amount of $\mathrm{GHG}$ emission from fuel-wood was due to the use of high amount of fuel-wood to fulfill energy demand. The methane emission leaked from the biogas plant without burning was not considered in the calculation of GHGs emission.

\section{Status of SHS}

All households had SHS, as there was no provision of grid electricity due to Chitwan National Park. In the study area, SHSs were installed both with subsidy (through AEPC and Indian Gover nment) and without subsidy scheme. Only in ward no. 5, SHSs were installed with subsidy scheme brought by Indian Ex-army through Indian Government. The used solar panel capacity ranged from 20-290 Wp. There was maximum use of solar panel of capacity ranging between 20Wp and $50 \mathrm{Wp}$, i.e. about $78 \%$ of which is slightly consistent with the result of TRUST (2003), i.e. the most popular size in Nepal is 35-45 Wp PV modules and 50\% of them were of $40 \mathrm{Wp}$. Moreover, the used solar battery capacity ranged from 35 to 175 Ah. About $40 \%$ of household used solar battery of capacity 57 Ah. Eighty one percent of household of study area used the solar battery ranged from 35 to 75 Ah that is nearly consistent with the result drawn by Khanal (2014) that 76\% battery range from 35 to $75 \mathrm{Ah}$. The result showed that there was maximum use of solar panel and battery having capacity $40 \mathrm{Wp}$ and $57 \mathrm{Ah}$ respectively. This might be because of the basic purpose of SHS (lighting, radio

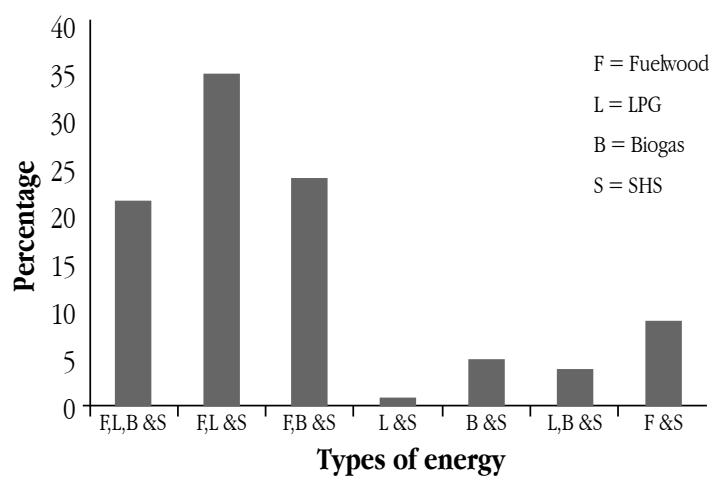

Figure 2 The different types of energy used and mobile charge) would be to fulfill through the capacity of SHS of that range. In addition, the larger capacity of SHS was used for TV, water pumping, inter net and fridge. From the study, it was found that the average lifetime of battery was 5 years. Though the guarantee given by suppliers was 2 years, it was found that many of the batteries were operational even for 5 years. It might be because of regular maintenance like supply of distilled water and placing it in safe place.

\section{Energy consumption activities of SHS}

Among the surveyed households, 100\% respondents were found to use SHS for lighting and mobile charge, as there was no grid electricity. The main reason for installation of SHS was lighting and mobile charge. In addition, TV, fan and others were also the reasons. Use of SHS was in accordance with capacity of solar panel and battery as well as the duration of light bulb use. The lar ger capacity of SHS was installed for the purpose of TV, fan, fridge, internet and water pumping.

\section{Management of damaged battery}

About $71 \%$ of the respondents used to sell damaged batter y to scrap collector. The scrap collector used to pay around Rs. 2000 for the used battery. Only $15 \%$ of the users used to return to the dealer for getting discount on new battery. In addition, rest 14\% of them used to throw away batter y because they did not know that battery could be retur ned to dealer and scrap collector . Dealers, suppliers, or users did not give attention on taking and returning back battery. Thus scrap collector collect all the non functional battery paying little price. Scrap collectors collect battery so as take and sell the lead present on the battery.

\section{GHG emission reduction due to installation of SHS}

SHS was the alternative and renewable energy technology in the study area. Due to the use of SHS, the use of 42 liters k erosene was displaced annually (3.5 liter/month) per household that largely reduced the emissions of GHGs. SHS reduced 0.11 ton of GHGs in terms of $\mathrm{CO}_{2}$-equivalent per household per year. The study carried out by Shakya and Shrestha (2006) showed that SHS replaced the use of kerosene for lighting purpose, which reduced 0.104 ton of $\mathrm{CO}_{2}$ emission annually that is nearly consistent with the result of the present study.

\section{Economic Benefit of SHS Simple cost payback period}

The cost payback period was calculated typically for $40 \mathrm{Wp}$ solar PV panel, as use of SHS with that capacity was maximum in number in the study area. Considering 25 years lifetime for solar panel and 5 years for battery; the payback period of SHS was found to be 9 , 7 and 2 years for no subsidy, with subsidy from AEPC and from Indian Government Grant, respectively, excluding inflation rate.

\section{喻TU-CDES}


Table 3 Calculation of simple cost payback period

\begin{tabular}{lccccc}
\hline Scheme & Cin & Cs & Com & Cs-Com & CPP \\
& (NRs) & (NRs) & (NRs) & (NRs) & (Year) \\
\hline Without subsidy & 23,000 & 4920 & 2400 & 2520 & 9 \\
With subsidy from AEPC & 17,000 & 4920 & 2400 & 2520 & 7 \\
With Indian Government & 6000 & 4920 & 2400 & 2520 & 2 \\
Grant & & & & & \\
\hline
\end{tabular}

Table 4 Calculation of Financial Benefit

\begin{tabular}{|c|c|c|}
\hline & \multicolumn{2}{|c|}{ Weekly Yearly (NRs) } \\
\hline Avg. kerosene consumption per HH (liter) & 0.87 & 42 \\
\hline Price of kerosene (NRs/liter) & & 110.0 \\
\hline Cost of kerosene consumed in 25 yrs (A) & & 459413.0 \\
\hline Operational \& maintenance cost in $25 \mathrm{yrs}$ & & 7500.0 \\
\hline Total cost of kerosene in 25 yrs $(\mathrm{A}+\mathrm{B})$ & & 466913.0 \\
\hline
\end{tabular}

The payback period of SHS was much less with Indian Govemment Grant compared to no subsidy scheme; this might be because of the greater subsidy amount, i.e. NRs 15,000. According to Hoque and Das (2013), the average value of cost payback period was found to be 4.2 years for $50 \mathrm{Wp}$ solar panel with the lifetime of 20 years, such a decrease in payback period might be because the average kerosene saved by $50 \mathrm{Wp}$ system was around 20.50 liter/month which was more than the result of the present study.

\section{Financial benefit}

It was found that the use of SHS with $40 \mathrm{Wp}$ capacity reduced the use of 42 liters (3.5 liter/month) of kerosene for lighting annually per household. The average monthly replacement of the kerosene for lighting after installation of SHS was estimated to be 4.48 liters per household per month (TRUST, 2003), which is a bit higher, but nearly consistent with the result (3.5 liters per month) obtained in this study. The reason behind heterogeneity in use of kerosene per month might be due to different $\mathrm{k}$ erosene consumption period, family size and place. The saving in total cost of kerosene to be consumed in 25 years could cover the cost of SHS installation. The cost saved from kerosene for lighting was NRs 4, 66,913, while taking a $9.47 \%$ inflation rate in kerosene and assuming that the baseline lighting kerosene remains unchanged for the period of 25 years.

\section{Cost benefit analysis}

The study showed that benefit-cost ratio was greater than one, which means the use of SHS is feasible. The benefit-cost ratio was found 3.1:1, 3.5:1 and 4.6:1 for no subsidy, subsidy from AEPC, and from Indian Government Grant, respectively.

\section{Conclusion}

Energy is the fundamental need of human. The present study has found that there was a substantial use of fuel-wood for cooking and preparation of animal feed along with LPG and biogas.

- All people use SHS for lighting, as the area was deprived of grid electricity, far from the major market centre (Bharatpur) and an availability of other energy sources in the area is limited.

- The use of kerosene was displaced for lighting (yearly 42 litre) due to installation of SHS, which reduced the emissions of GHGs to large extent.

- The SHS was found to be economically beneficial as benefitcost ratio was found to be 3.1:1, 3.5:1 and 4.6:1 for system with no subsidy, subsidy from AEPC and from Indian Government Grant respectively.

- Thus, SHS is one of the best alter natives in reduction of $\mathrm{CO}_{2}$ emission by replacing bur ning kerosene for lighting and is economically beneficial.

\section{Acknowledgements}

Authors would like acknowledge the Central Department of Environmental Science, Tribhuvan University for providing the Innovative Research Grant (IRG).

\section{References}

AEPC (2010). Annual Progress Report 2009/10, Ministry of Environment. Khumaltar, Lalitpur: Alternative Energy Promotion Centre.

AEPC/ESAP (2010). Status of Solar Photovoltaic Sector in Nepal. Alternative Energy Promotion Centre / Energy Sector Assistance Programme.

AEPC (2013). A year in review, NYF 2012/13: Making Renewable Energy Mainstream Supply to Rural Areas of Nepal. Khumaltar, Lalitpur: Ministry of Science, Technology and Environment, Alternative Energy Promotion Centre.

AEPC/NRREP (2014). Solar Home System / Small Solar Home System under Subsidy Programme, till fiscal year 2014. Alternative Energy Promotion Centre/National Rural and Renewable Energy Programme.

CBS (2012). National Population and Housing Census, 2011 (Village Development Committee/Municipality. Kathmandu, Nepal: Government of Nepal, National Planning Commission Secretariat, Central Bureau of Statistics.

CRT/N (2005). National Energy Situation Survey Report NepalFocus on Renewable Energy and Poverty Reduction. Kathmandu, Nepal: Centre for Rural Technology, Nepalsubmitted to International Network for Sustainable Energy.

Dhoubhadel, S. (2010). Cost-benefit analysis of Solar PV system. Khumaltar, Lalitpur. Submitted to Solar Energy Component. Energy Sector Assistant Program, Alternative Energy Promotion Center. 
EPA (2014). Emission Factor for Green House Gas Inventories, Last Modified 4th April, 2014 Climate Registry Default Emission Factor, Environmental Protection Agency.

Hoque, S.M.N. \& Das, B.K. (2013). Analysis of Cost, Energy and $\mathrm{CO}_{2}$ Emission of Solar Home Systems in Bangladesh. International Journal of Renewable Energy Research, 3. Khanal, S. (2014). A Study of Solar Home System (SHS) and Used Lead Acid Battery Management Practices in Nepal: A case study of Sankhuwasabha and Morang districts. A thesis submitted to Central Department of Environmental Science, TU, Kirtipur, Nepal.

Malla, A. \& Niraula, A. (2012). Importance of Balance of System in Solar PV Application. Rentech Symposium Compendium, 2. NRB (2014). Quaterly Economic Bulletin - Vol. 48. Research Development, Nepal Rastra Bank, Baluwatar, Kathmandu, Nepal. Retrieved from http://red.nrb.org.np/publications/ economic_bulletin/Quarterly_Economic_Bulletin-201401_(Mid-January)-New.pdf.

NRB (2014, April). www.tradingeconomics.com. (N. R. Bank, Producer). Retrieved from http://www.tradingeconomics.com/nepal/inflation-cpi.

NREL (2014). Last updated, May 7, 2014 by Mathias Asrie Maeblum, National Renewable Energy Laboratory. Retrieved April 2014, from http://energyinformative.org/lifespan-solar-panels/.
Paudyal, A. (2007). Buffer Zone Resources and Community Conservation: a case study of Piple Buffer Zone Village Development Committee, Chitwan National Park. Msc Thesis submitted to Central Department of Environmental Science TU, Kirtipur, Nepal.

Shakya, S.R. \& Shrestha, J.N. (2006). Contribution of Renewable Energy Technology for GHG mitigation in Nepal. Proceeding of First National Conference on Renewable Energy Technology for Rural Development. Kathmandu, Nepal

Shively, G., \& Galopin, M. (2014). An overview of benefit-cost analysis. Retrieved from http://www.agecon.purdue.edu/staff/ shively/COURSES/AGEC406/reviews/bca.htm

TRUST (2003). Final Draft Report on User's Survey on Productive End-Use and Impact Assessment of Solar Home System Dessemination Programme. Kathmandu, Nepal: Technology and Rural Upliftment Service Team.

Upadhaya, S. (2008). Energy Crises and Nepal's Potentially. Kathmandu Forestry College. Kathmandu, Nepal: The Initiation. WECS (2010). Energy Sector Synopsis Report. Kathmandu, Nepal: Water and Energy Commission Secretariat. 